\title{
MIXED SYMMETRIC MEANS RELATED TO THE CLASSICAL JENSEN'S INEQUALITY
}

\author{
KHURAM Ali KHAN AND JOSIP PEČARIĆ
}

Abstract. In this paper, we define some new mixed symmetric means corresponding to various refinements of classical Jensen's inequality. A new refinement of classical Jensen's inequality is given. We also prove the $n$-exponential convexity for the functionals constructed from the refinement results. In the end some applications are discussed.

Mathematics subject classification (2010): Primary 26D07, 26D15, 26D20, 26 D99.

Keywords and phrases: Convex function, Jensen's inequality, mixed symmetric means, exponentially convex function.

\section{REFERENCES}

[1] M. Anwar And J. PeČarić, New Means of Cauchy type, J. Inequal. Appl. Vol. 2008 (2008), Article ID 163202, 10 pages.

[2] M. AnwAR AND J. PeČARIĆ, On log-convexity for differences of mixed symmetric means, Mathematical Notes 88, 6 (2010), 776-784.

[3] S. S. DRAGOMIR AND J. PeČARIĆ, On an inequality of GodunovaLevin and some refinements of Jensen integral inequality, Babes-Bolyai, Univ. Fac. Math. Res. Sem. Prep. No.6, 263-268, 1989.

[4] E. Hewitt And K. R. Stromberg, Real and abstract analysis, Graduate Text in Mathematics 25, Springer-Verlag, Berlin-Heidelberg-New York (1965).

[5] L. Horváth, Inequalities Corresponding to the Classical Jensen's Inequality, J. Math. Inequal. 3, 2 (2009), 189-200.

[6] L. Horváth, K. A. Khan And J. PeČArić, Refinements of Results about Weighted Mixed Symmetric Means and Related Cauchy Means, J. Inequal. Appl. Vol. 2011 (2011), Article ID 350973, 19 pages.

[7] J. JAKŠETIĆ AND J. PeČARIĆ, Exponential Convexity Method, submitted.

[8] K. A. Khan, J. PeČArIĆ AND I. Perić, Differences of weighted mixed symmetric means and related results, J. Inequal. Appl. Vol. 2010 (2010), Article ID 289730, 16 pages.

[9] D. S. Mitrinović, J. PeČArić And A. M. Fink, Classical and New Inequalities in Analysis, Kluwer Acadenic Publishers, 1993.

[10] J. PEČARIĆ, Extension of interpolation of Jensen's Inequality, Mat. Bilten (Skopje) 15 (1991), 39-40.

[11] J. PEČARIĆ AND J. PERIĆ, Improvement of the Giaccardi and the Petrović Inequality and Related Stolarsky Type Means, submitted.

[12] J. Pečarić, F. Proschan and Y. L. Tong, Convex functions, Partial Orderings and Statistical Applications, Academic Press, New York, 1992.

[13] I. RASA, On the monotonicity of sequences of Bernstein-Schnab operators, Ann. Numer. Theor. Approx. 17 (1988), 185-187.

[14] D. V. WidDER, The Laplace Transform, Princeton Uni. Press, New Jersey, 1941. 